\title{
ANALISIS FINANCIAL DEEPENING DI INDONESIA
}

\author{
Dede Ruslan \\ Fakultas Ekonomi Universitas Negeri Medan
}

\begin{abstract}
This paper aims to analize the financial deepening on Indonesia economy. The focus of analysize is to identifiying effect of interest rate, exchange rate and Gross Domestic Product (GDP) to financial deepening on Indonesian economy for 1980-2007. Methode of analysize is linier regression model. The result of analysize are Gross Domestic Product (GDP) and interest rate have significant effect to financial deepening on Indonesian economy.
\end{abstract}

Keywords : financial deepening, linier regression model, gross domestic product

\section{A. LATAR BELAKANG}

Pembangunan ekonomi suatu negara tidak dapat dilepaskan dari sektor keuangan. Sektor keuangan dapat berperan dalam menjalankan fungsinya sebagai intermediary function. Dalam pembangunan sektor keuangan, suatu negara dihadapkan pada kondisi sektor keuangan yang mengalami pendalaman (financial deepening) dan sektor keuangan yang mengalami pendangkalan (shallow finance) (Fry, 1995:20).

Keberadaan sektor keuangan dalam perekonomian suatu negara memiliki peran penting dalam upaya untuk meningkatkan pertumbuhan ekonomi.. Sektor keuangan yang berkembang dengan baik, maka akan dapat mendorong kegiatan perekonomian. Sebaliknya sektor keuangan yang tidak dapat berkembang dengan baik, maka akan menyebabkan perekonomian mengalami hambatan likuiditas dalam upaya mencapai pertumbuhan ekonomi yang tinggi (Brandl, 2002:4). Secara lebih spesifik Dornbusch dan Reynoso (1989:204) menyatakan bahwa suatu negara akan berhasil dalam mencapai sasaran dalam pembangunan ekonominya, bila sektor keuangannya dapat berkembang dengan baik. Perkembangan sektor keuangan ini dapat dilihat dari kemampuannya dalam menyediakan tabungan yang cukup bagi keperluan investasi pembangunan maupuan dalam mengatasi masalah-masalah seperti pembiayaan inflasi dan pengaruh defisit anggaran terhadap pertumbuhan ekonomi.

Keberadaan sektor keuangan dalam perekonomian dapat dilihat dari beberapa indikator. Pendapat yang dikemukakan oleh Lynch (1996:3-33) menunjukkan bahwa terdapat 5 indikator untuk mengetahui perkembangan sektor keuangan suatu negara, yakni; indikator kuantitatif, indikator struktural, indikator harga, indikator skala produk dan indikator biaya transaksi.

Berkaitan dengan indikator kuantitatif tersebut, perkembangan sektor keuangan dalam perekonomian dapat diukur dengan engan menggunakan rasio antara aset keuangan dalam negeri terhadap PDB (seperti: rasio M1/GDP, M2/GDP, M3/GDP, M4/GDP). Rasio yang semakin besar menunjukkan semakin dalam sektor keuangan suatu negara (financial deepening). 
Sebaliknya semakin kecil rasionya menunjukkan semakin dangkal sektor keuangan suatu negara (shallow finance). Dalam hal ini pertumbuhan ekonomi yang tinggi dapat dicapai apabila sektor keuangan yang mengalami financial deepening (Okuda, 1990:270).

Guna meningkatkan peran sektor keuangan agar mencapai kondisi financial deepening, dibutuhkan berbagai upaya strategis. Upaya tersebut meliputi suatu rencana dan implementasi dari kebijakan untuk mengintensifkan tingkat moneterisasi perekonomian melalui peningkatan dalam akses terhadap institusi finansial, transparansi dan efisiensi, serta mendorong peningkatan rate of return yang rasional (Agrawal, 2001:83).

Indonesia sebagai negara sedang berkembang memiliki karakter yang tidak berbeda jauh dengan negara sedang berkembang lainnya. Tujuan pencapaian tingkat pertumbuhan eknomi yang tinggi dalam proses pembangunannya dihadapkan pada permasalahan dalam keterbatasan modal untuk membiayai investasi pembangunan. Berbagai upaya telah dilakukan guna meningkatkan peran sektor keuangan dalam pembiayaan pembangunan secara mandiri dan tidak tergantung dari bantuan luar negeri.

Upaya ini dimaksudkan agar terjadi financial deepening dalam perkembangan sektor keuangan dalam perekonomian nasional. Diantaranya adalah berkenaan dengan kebijaksanaan di sektor keuangan dan moneter pada tahun 1980 an seperti ; kebijaksanaan paket Juni 1983 yang mencakup pembebasan kredit dan pagu kredit bagi operasi bank-bank negara dan memperkenalkan instrumen pengendalian moneter baru yang berorientasi pasar, paket Oktober 1987, paket Desember 1988 dan paket Maret 1989 yang kesemuanya diarahkan pada perbaikan kebijakan efisiensi sektor keuangan dan pengembangan pasar modal. Diantaranya adalah melalui pembukaan hambatan arus modal masuk. Kemudian disusul dengan adanya regulasi baru yang diumumkan pada tanggal 14 Maret 1991, ditujuan untuk memperkuat basis permodalan bankbank dan memperketat pengawasan terhadap lembaga-lembaga keuangan (Nasution, 1991:34).

Berdasarkan pada uraian di atas, maka permasalahan yang akan diteliti dalam penelitian ini adalah: apakah variabel tingkat bunga, nilai tukar dan variabel pendapatan nasional berpengaruh secara signifikan terhadap variabel financial deepening Indonesia dari tahun 1980 sampai dengan tahun 2007; dan juga melihat variabel mana yang memiliki pengaruh dominan terhadap variabel financial deepening Indonesia dari tahun 1980 sampai dengan tahun 2007.

\section{B. TINJAUAN TEORI}

\section{Financial Deepening}

Keberadaan sektor keuangan dapat dilihat dari beberapa indikator dalam perkembangannya. Dalam hal ini terdapat beberapa pandangan mengenai indikator untuk mengetahui perkembangan sektor keuangan di suatu negara. Diantaranya pendapat yang dikemukakan oleh Lynch (1996:333) yang menyatakan terdapat 5 indikator untuk mengetahui perkembangan sektor keuangan suatu negara, yakni : 
1) Ukuran Kuantitatif (Quantity Measures)

Indikator kuantitatif bersifat moneter dan kredit, seperti rasio uang dalam arti sempit terhadap PDB, rasio uang dalam arti luas terhadap PDB dan rasio kredit sektor awsata terhadap PDB. Indikator kuantitatif ini untuk mengukur pembangunan dan kedalaman sektor keuangan.

2) Ukuran Struktural (Structural Measures)

Indikator struktural menganalisa struktur sistem keuangan dan menentukan pentingnya elemen-elemen yang berbeda-beda pada sistem keuangan. Rasio-rasio yang digunakan sebagai indikator adalah : rasio uang dalam arti luas terhadap PDB, rasio pengeluaran pasar sekuritas terhadap uang dalam arti luas.

3) Harga sektor keuangan (Financial Prices)

Indikator ini dilihat dari tingkat bungan kredit dan pinjaman sektor riil.

4) Skala Produk (Product Range)

Indikator ini dilihat dari berbagai jenis-jenis instrumen keuangan yang terdapat di pasar keuangan, seperti ; produk keuangan dan bisnis (commercial paper,corporate bond, listed equity), produk investasi, produk pengelolaan risiko dan nilai tukar luar negeri.

5) Biaya Transaksi (Transaction Cost)

Indikator ini dilihat dari spread suku bunga.

Berkaitan dengan indikator kuantitatif untuk melihat perkembangan sektor keuangan dalam pembangunan dengan menggunakan rasio antara aset keuangan dalam negeri terhadap PDB (seperti : rasio M1/GDP, M2/GDP, M3/GDP, M4/GDP), maka perkembangan dalam rasio aset keuangan terhadap PDB menunjukkan pendalaman keuangan. Perkembangan yang semakin besar dalam rasio tersebut menunjukkan semakin dalam sektor keuangan suatu negara. Sebaliknya semakin kecil rasio tersebut menunjukkan semakin dangkal sektor keuangan suatu negara (Okuda, 1990:270).

Pendalaman keuangan (financial deepening) menurut Shaw (1973) merupakan akumulasi dari aktiva-aktiva keuangan yang lebih cepat dari pada akumulasi kekayaan yang bukan keuangan (Kitchen, 1988:14). Pendalaman keuangan ditunjukkan oleh semakin besarnya rasio antara jumlah uang beredar (M2) dengan PDB. Sebaliknya semakin kecil rasio antara jumlah uang beredar (M2) dengan PDB menunjukkan semakin dangkal sektor kuangan suatu negara (Lynch, 1996:3).

Nasution (1990) dalam kaitannya dengan pendalaman keuangan mengatakan bahwa ukuran pendalaman keuangan suatu negara ditunjukkan oleh rasio antara jumlah kekayaan yang dinyatakan dengan uang (financial asset) dengan pendapatan nasional. Semakin tinggi rasionya mempunyai arti bahwa penggunaan uang dalam perekonomian suatu negara semakin dalam. Semakin tinggi pendalaman keuangan semakin besar penggunaan uang dalam perekonomian dan semakin besar serta semakin meluas kegiatan lembaga keuangan maupun pasar uang dalam perekonomian (Wardhana, 1998:5). 


\section{Faktor-faktor Yang Mempengaruhi Financial Deepening}

\section{Pengaruh Nilai Tukar Mata Uang Terhadap Financial Deepening}

Naik turunnya nilai tukar mata uang pada dasarnya dipengaruhi oleh banyak faktor sesuai dengan sistem yang dianutnya. Dalam sistem nilai tukar tetap, maka nilai kurs mata maung domestik terhadap mata uang asing besar kecilnya ditentukan oleh kebijakan pemerintah. Sdangkan dalam sistem nilai tukar mengambang, maka nilai tukar mata uang dipengaruhi oleh faktor-faktor seperti jumlah uang beredar, inflasi tingkat bunga dan pendapatan (Kuncoro, 1996:157).

Baik dalam sistem nilai tukar tetap maupun dalam sistem nilai tukar mengambang fluktuasi nilai tukar mata uang dapat berdampak pada perekonomian. Suatu apresiasi mata uang domestik terhadap mata uang asing dapat menyebabakan semakin meningkatnya permintaan masyarakat akan barang dan jasa. Bila terjadi keadaan over demand, maka hal tersebut dapat mengakibatkan inflasi yang tinggi.

Sedangkan apabila mata uang uang domestik mengalami depresiasi terhadap mata uang asing, maka yang hal tersebut dapat mengakibatkan masyarakat akan terus memburu mata uang asing. Kondisi ini dikarenakan masyarakat akan menyimpan sebagian kekayaan dalam bentuk mata uang asing. Sehingga secara umum depresiasi nilai tukar mata uang akan berdampak negatif terhadap financial deepening.

\section{Pengaruh Pendapatan Nasional Terhadap Financial Deepening}

Dalam pengertian ekonomi mikro pendapatan merupakan insentif yang diperoleh masyarakat dari kegiatan usahanya. Semakin tinggi pendapatan menunjukkan semakin besarnya insentif yang diterima masyarakat dalam kegiatan ekonomi. Pendapatan yang tinggi tersebut pada akhirnya berdampak pada semakin tinggi pula permintaan terhadap barang dan jasa dalam perekonomian.

Dalam konteks makro ekonomi pendapatan diartikan sebagai keseluruhan barang dan jasa (output) yang dihasilkan oleh perekonomian suatu negara pada suatu periode waktu tertentu. Pendapatan yang tinggi menandakan bahwa output yang dihasilkan oleh perekonomian menjadi meningkat. Secara umum semakin tinggi pendapatan masyarakat, maka akan semkain meningkatkan financial deepening.

\section{Pengaruh Tingkat Bunga Terhadap Financial Deepening}

Berkaitan dengan peranan tingkat bunga terhadap pendalaman keuangan (financial deepening), maka McKinnon dan Shaw pada tahun 1973 menguraikan suatu teori yang dijadikan dasar bagi pengambilan kebijakan di sektor keuangan di negara sedang berkembang pada tahun 1980-an Pandangan McKinnon dan Shaw mengenai peranan suku bunga sangat terkait dengan adanya kebijakan represi keuangan (financial repression) yang terjadi dalam perekonomian suatu negara. Menurutnya represi keuangan yang salah satunya adalah ditandai oleh adanya pembatasan dalam tingkat bunga (suku bunga riil rendah) dalam perekonomian, justru dapat menyebabkan rendahnya minat masyarakat untuk menyimpan dananya di bank dan pada akhirnya suplai dana investasi akan berkurang. 
Guna mengatasi hal tersebut, maka McKinnon dan Shaw merekomendasikan kebijakan liberalisasi keuangan yakni dengan adanya kebijakan tingkat bunga sesuai dengan mekanisme pasar. Kenaikan tingkat bunga berarti adanya peningkatan insentif yang dapat dinikmati oleh masyarakat, sehingga masyarakat akan terdorong untuk menyimpan dananya di bank. Hal ini berarti adanya akumulasi modal yang dapat digunakan untuk pembiayaan pembangunan. Secara lebih rinci uraian McKinnon dan Shaw mengenai liberalisasi keuangan dapat dilihat pada gambar berikut (Fry, 1995:24).

Tingkat tabungan $\mathrm{S}\left(\mathrm{y}_{\mathrm{o}}\right)$ pada tingkat pendapatan $\mathrm{y}_{\mathrm{o}}$ merupakan fungsi dari tingkat bunga. Notasi F menunjukkan pembatasan keuangan (financial constraint) dan notasi I menunjukkan tingkat investasi pada tingkat awal dan $\mathrm{r}_{\mathrm{o}}$ merupakan tingkat bunga riil pada tingkat awal. Dalam hal ini kondisi represi keuangan terjadi pada tingkat bunga riil $\mathrm{r}_{\mathrm{r}}$. Tingkat tabungan pada keadaan ini ditunjukkan pada kurva $\mathrm{S}\left(\mathrm{y}_{\mathrm{o}}\right)$. Sehingga tingkat investasi yang ada hanya terbatas pada Io.

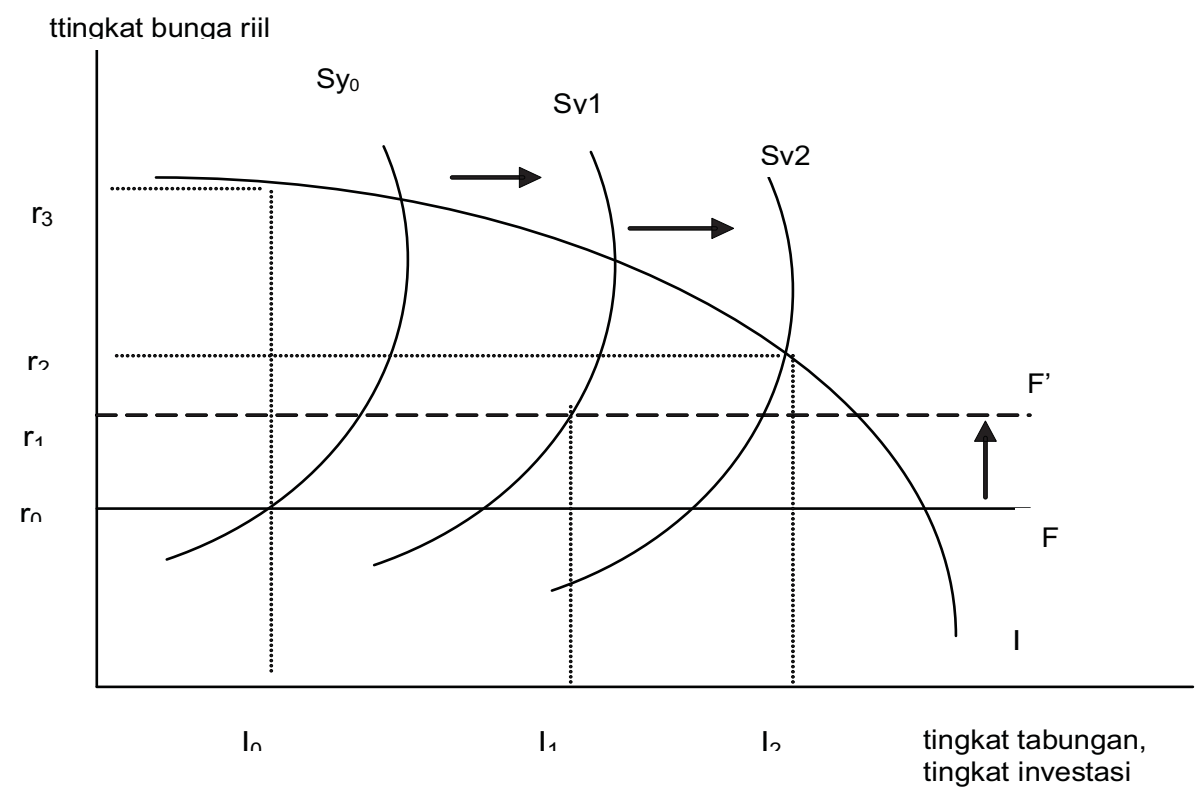

Gambar 1. Hubungan Tingkat Bunga Dengan Investasi

Liberalisasi keuangan dapat dilihat dari pergerakan ke atas dari garis $\mathrm{F}$ menjadi garis F'. Hal ini menyebabkan suku bunga riil lebih tinggi dari tingkat sebelumnya, baik $r_{o}$ maupun $r_{1}$. Kenaikan dalam tingkat bunga riil ini akan diikuti dengan adanya kenaikan dalam tingkat tabungan yang dapat dihimpun oleh bank dari masyarakat. Meningkatnya tingkat tabungan dalam perbankan ini dapat dimanfaatkan oleh investor untuk membiayai proyeknya, sehingga dapat meningkatkan kegiatan ekonomi dan pada akhirnya pertumbuhan ekonomi dapat meningkat. Tingkat tabungan meningkat dari $\mathrm{S}\left(\mathrm{y}_{\mathrm{o}}\right)$ menjadi $\mathrm{S}\left(\mathrm{y}_{1}\right), \mathrm{S}\left(\mathrm{y}_{2}\right)$ dan seterusnya seiring dengan kenaikan dalam tingkat bunga. Sedangkan tingkat investasi akan meningkat dari $\mathrm{I}_{\mathrm{o}}$ menjadi $\mathrm{I}_{1}, \mathrm{I}_{2}$ dan seterusnya. 
Hubungan antara tingkat bunga dengan tingkat tabungan merupakan elemen penting dalam teori McKinnon dan Shaw. Menurut McKinnon dan Shaw terdapatnya kenaikan dalam tingkat bunga menyebabkan meningkatnya tabungan masyarakat pada perbankan. Peningkatan tabungan ini merupakan indikator peningkatan dalam jumlah uang beredar di masyarakat yang diakumulasikan dalam bentuk tabungan.

\section{Penelitian Sebelumnya}

Dalam kaitannya dengan perkembangan sektor finansial suatu negara, terdapat banyak hasil penelitian empiris yang dilakukan oleh peneliti-peneliti sebelumnya. Agrawal (2001:83-93) meneliti pengaruh suku bunga, nilai tukar dan produk domestik bruto (PDB) terhadap financial deepening di negara Asia, seperti ; Indonesia, Korea Selatan, Malaysia dan Thailand. Dalam pengamatannya selama pertengahan tahun 1960 an sampai pertengahan tahun 1990 an Agrawal menggunakan rasio antara jumlah uang beredar (M2) dengan PDB sebagai variabel financial deepening di 4 negara tersebut. Hasil dari penelitiannya dengan menggunakan error correction model dan uji kointegrasinya menunjukkan bahwa rasio dalam finacial deepening umumnya meningkat seiring dengan peningkatan dalam suku bunga dan dengan terjadinya depresiasi mata uang domestik terhadap US\$. Suku bunga yang tinggi tersebut menyebabkan masuknya asetaset luar negeri ke dalam sistem perbankan masing- masing negara. Kenaikan dalam suku bunga tersebut juga berdampak pada kenaikan dalam rasio investasi dalam perekonomian. Sehingga dalam implikasi kebijakan, Agrawal menyarankan adanya liberalisasi dalam suku bunga dalam negara-negara tersebut, meskipun harus dilakukan secara bertahap dan dengan kontrol yang baik guna meminimalkan potensi risiko finansial yang terjadi.

Penelitian Oleh Cull (2001:269-290) dengan menggunakan analisa cross section selama 3 tahun di berbagai negara penerima pinjaman bank dunia, financial development diurai menjadi 4 variabel, yakni rasio M2/GDP, rasio Kredit swasta dalam negeri/GDP, rasio Quasi money/ GDP dan rasio liabiliti likuid/GDP. Sedangkan yang mempengaruhi variabel financial development seperti ; besarnya kredit swasta pada saat awal, inflasi, populasi, pendapatan perkapita, pinjaman sektor, perubahan institusi bank, privatisasi bank, adanya Effective Development Assistance dan kebijaksanan pemerintah. Penelitian Cull yang bertujuan untuk mengetahui faktorfaktor yang mempengaruhi variasi dalam financial development di berbagai negara akibat adanya pinjaman dari bank dunia menunjukkan bahwa pinjaman bank dunia dapat meningkatkan rasio dalam indikator financial development di negara penerima bantuan. Selain itu pula Cull juga menyimpulkan bahwa financial development dapat berkembang dengan cepat di negara yang memiliki tingkat inflasi rendah, jumlah penduduk yang tinggi, kebijakan pemerintah yang kondusif dan adanya kebijakan Effective Development Assistance.

Penelitian oleh King dan Levine (1993:717-737) terhadap 80 negara selama tahun 19601989 melihat hubungan kausalitas antara financial deepening dengan tingkat pertumbuhan ekonomi suatu negara. Dalam penelitiannya tersebut King dan Levine menjabarkan financial deepening menjadi 4 variabel, yakni : rasio antara jumlah uang beredar (M2) terhadap PDB, alokasi kredit domestik oleh bank sentral, persentase kredit yang dialokasikan terhadap sektor swasta, dan rasio kredit sektor swasta terhadap PDB. Sedangkan pertumbuhan ekonomi dilihat dari perubahan dalam PDB perkapita. Hasil penelitiannya menunjukkan bahwa pertumbuhan ekonomi tidak menyebabkan financial deepening. 


\section{Hipotesa Penelitian}

Hipotesis yang diajukan dalam penelitian ini adalah :

1 Diduga variabel tingkat suku bunga, nilai tukar dan variabel tingkat pendapatan nasional berpengaruh secara signifikan terhadap variabel financial deepening Indonesia dari tahun 1980 sampai dengan tahun 2007.

2 Diduga variabel tingkat bunga memiliki pengaruh dominan terhadap variabel financial deepening Indonesia dari tahun 1980 sampai dengan tahun 2007.

\section{METODE PENELITIAN DAN ANALISIS DATA}

\section{Jenis dan Sumber Data}

Penelitian ini menggunakan data sekunder time series selama tahun 1980 sampai dengan 2009. Pemilihan waktu penelitian ini didasarkan pada pertimbangan bahwa selama periode tersebut perekonomian nasional dihadapkan pada tatanan perekonomian baru yang lebih mengglobal. Hal ini diwujudkan dengan keikutsertaan Indonesia dalam forum kerja sama ekonomi dunia , seperti APEC, WTO, dan AFTA. Dalam hal ini sektor keuangan memiliki peran penting guna menjga stabnilitas perekonomian secara makro.

Berbagai sumber data yang dimaksud seperti data dari Statistik Ekonomi dan Keuangan Indonesia (laporan Bank Indonesia), International Financial Statistics - IMF, Indikator Ekonomi (BPS) dan data dari Asian Development Bank Report dari berbagai edisi.

\section{Teknik Pengumpulan Data}

Teknik pengumpulan data yang dilakukan dalam penelitian ini dengan menggunakan teknik dokumenter. Teknik ini dilakukan dengan cara mengumpulkan data dari berbagai sumber data yang tersedia.

\section{Variabel Penelitian dan Skala Pengukurannya}

Adapun variabel-variabel yang digunakan dalam penelitian ini dapat dijelaskan sebagai berikut :

a. Tingkat Bunga

Tingkat bunga merupakan biaya dari penggunaan uang. Dalam penelitian ini tingkat bunga diproksi dengan tingkat bunga deposito riil 6 bulan bank-bank pemeintah. Tingkat bunga riil dapat diperoleh dengan melakukan pengurangan tingkat bunga nominal dengan tingkat inflasi. Sedangkan tingkat inflasi diperoleh dengan cara menghitung perubahan Indek Harga Konsumen (IHK berdasarkan tahun dasar 2000) pada suatu periode waktu dibandingkan dengan IHK periode sebelumnya. Data tingkat bunga nominal diperoleh dari Statistik Ekonomi dan Keuangan Indonesia (Bank Indonesia) dan data IHK diperoleh dari World Development Report berbagai edisi. 


\section{b. Pendapatan Nasional}

Pendapatan nasional merupakan keseluruhan dari barang dan jasa yang dihasilkan penduduk di suatu wilayah pada tahun tertentu. Dalam penenlitian ini pendapatan nasional diproksi dengan nilai Produk Domestik Bruto (PDB). Data PDB yang digunakan dalam penelitian ini adalah PDB riil berdasarkan IHK tahun dasar 2000 yang mencerminkan PDB sesungguhnya yang dihasilkan oleh perekonomian suatu wilayah setelah dieliminir dari pengaruh perubahan harga. Data PDB dalam satuan Milyar Rupiah dan diperoleh dari publikasi Asian Development Bank berbagai edisi.

\section{c. Finacial Deepening}

Financial deepening menurut Shaw (1973) merupakan akumulasi dari aktiva-aktiva keuangan yang lebih cepat dari pada akumulasi kekayaan yang bukan keuangan (Kitchen, 1988:14). Financial deepening ditunjukkan oleh semakin besarnya rasio antara jumlah uang beredar (M2) dengan PDB. Dalam penelitian ini financial deepening diproksi dengan jumlah uang beredar dalam arti luas (M2) trhadap PDB. M2 dalam penelitian ini meliputi uang kartal, uang giral, deposito berjangka (time deposit) dan tabungan (saving deposit). Guna mengeliminir dari adanya perubahan harga, maka dalam penelitian ini menggunakan nilai M2 riil berdasarkan IHK tahun dasar 2000. Data PDB dalam penelitian ini juga menggunakan data PDB riil berdasarkan IHK tahun dasar 2000. Sehingga rasio jumlah uang beredar (M2) terhadap PDB merupakan nilai riil yang dihitung berdasarkan IHK tahun dasar 2000. Data jumlah uang beredar (M2) dalam satuan Milyar Rupiah diperoleh dari Statistik Ekonomi dan Keuangan Indonesia (Bank Indonesia). Sedangkan data PDB dalam Milyar Rupiah diperoleh dari publikasi Asian Development Bank berbagai edisi.

\section{d. Nilai Tukar}

Nilai tukar merupakan harga relatif suatu mata uang dibandingkan dengan mata uang lain. Dalam penelitian ini nilai tukar yang digunakan adalan kurs akhir tahun nilai tukar Rupiah terhadap US\$. Data nilai tukar Rupiah terhadap US\$ diperoleh dari Statistik Ekonomi dan Keuangan Indonesia (Bank Indonesia) dan publikasi Asian Development Bank berbagai edisi.

\section{Teknik Analisis Data}

Teknik analisis yang digunakan dalam penelitian ini adalah menggunakan metode regresi linier berganda. Sesuai dengan perumusan masalah dan tujuan penelitian, maka model yang dikembangkan dalam penelitian ini adalah :

$\mathrm{M} 2 / \mathrm{Y}=\mathrm{f}(\mathrm{Y}, \mathrm{RER}, \mathrm{IR}$,

Model tersebut dibuat dalam persamaan regresi menjadi : dimana :

$\mathrm{M} 2 / \mathrm{Y}=\mathrm{a}_{\mathrm{o}}+\mathrm{a}_{1} \mathrm{PDB}+\mathrm{a}_{2} \mathrm{RER}+\mathrm{a}_{3} \mathrm{IR}+\mathrm{e}$

$\begin{array}{ll}\mathrm{M} 2 / \mathrm{Y} & =\text { financial deepening } \\ \mathrm{PDB} & =\text { pendapatan nasional } \\ \mathrm{RER} & =\text { nilai tukar riil Rupiah terhadap US\$ } \\ \mathrm{IR} & =\text { tingkat suku bunga riil } \\ \mathrm{e} & =\text { Error Term }\end{array}$




\section{Uji-uji Yang Dilakukan}

Dalam uji ini terdapat dua tahap, yakni uji tahap pertama dan uji tahap kedua. Uji tahap pertama terdiri dari uji t dan uji F. Uji t dilakukan untuk mengetahui signifikansi pengaruh variabel bebas terhadap variabel tidak bebas secara individu. Sedangkan uji F dilakukan untuk mengetahui pengaruh variabel bebas terhadap variabel tidak bebas secara bersma-sama

Uji tahap berikutnya adalah uji tahap kedua yang meliputi uji homoskedastis, uji autokorelasi, uji linieraitas dan uji normalitas. Uji homoskedastis merupakan salah satu asumsi klasik yang harus dipenuhi oleh penaksir $O L S$. Penyimpangan terhadap asumsi homoskedastis tersebut disebut sebagai heteroskedastisitas. Homoskedastis dapat terjadi bila distribusi suatu probabilitas tetap sama dalam semua observasi $X$, dan varian setiap residual adalah sama untuk semua nilai variabel penjelas. Guna mengetahui heteroskedastisitas dilakukan dengan menggunakan Uji Park.

Autokorelasi dapat terjadi bila variabel gangguan pada periode tertentu berkorelasi dengan variabel gangguan pada periode yang lain. Bila hal ini terjadi, maka akan dihasilkan penaksir yang tidak efisien, walaupun estimasinya tidak bias. Guna mendeteksi terjadinya gejala autokorelasi dapat dilakukan dengan adalah uji lagrange multiplier.

Uji linieritas digunakan untuk melihat spesifikasi model yang akan digunakan dalam estimasi sudah benar atau belum. Uji linearitas dilakukan karena adanya kesalahan spesifikasi model dapat berakibat ketidakefisienan dari penaksir. Guna mengetahui linearitas model, maka digunakan general test of spesification/Ramsey RESET Test.

Asumsi normalitas dalam model linier klasik berarti bahwa variabel pengganggu terdistribusi secara normal. Bila asumsi ini tidak terpenuhi dalam model estimasi, maka koefisien parameter masih tidak bias dan terbaik tetapi tidak dapat dilakukan penaksiran terhadap reliabilitas dengan uji signifikansi klasik, baik uji F ataupun uji t (Koutsoyiannis, 1985:197). Dalam hal ini uji JarqueBera Lagrange Multiplier dapat digunakan untuk menguji kenormalan variabel pengganggu dalam suatu model.

\section{HASIL DAN PEMBAHASAN}

Dinamika perekonomian Indonesia selama periode 1980 - 2007 menunjukkan fluktuasi dalam perkembangannya. Krisis keuangan dan moneter yang melanda dunia pada tahun 19971998 membawa dampak contagion effect yang menyebabkan tergerusnya fundamental perekonomian nasional. Indikator makroekonomi seperti pertmbuhan ekonomi, kurs, tingkat suku bunga perbankan dan kesempatan kerja mengalami tekanan yang cukup signifikan. Pertumbuhan ekonomi yang menjadi tolak ukur penting dalam mengukur kinerja perekonomian di Indonesia mengalami penurunan yang cukup drastik hingga mencapai angka minus pada tahun 1998 . Walaupun secara agregat terjadi kenaikan terhadap angka PDB Indonesia, namun nilai tersebut belum mampu meningkatkan laju pertumbuhan output nasional dari waktu ke waktu. Belum genap masa recovery perekonomian nasional, krisis lanjutan yang menghantam sektor keuangan global terjadi pada periode 2006-2007. Krisis tersebut ditandai dengan banyaknya perusahaanperusahaan keuangan, perusahaan otomotif, elektronik dan manufaktur yang mengalami kebangkrutan hingga penutupan beberapa perusahaan yang ada. Namun demikian belajara dari krisis yang terjadi sebelumnya perekonomian nasional masih dapat bertahan dalam situasi perekonomian global yang tidak menentu. 
Secara garis besar perkembangan perekonomian nasional selama periode 1980-2007 dapat dijelaskan sebagai berikut ini:

\section{Kurs}

Perkembangan kurs Rp/US\$ berdasarkan perhitungan nilai rata-rata selama periode tertentu di Indonesia menunjukkan fluktuasi sesuai dengan dinamika yang terjadi dalam perekonomian nasional. Selama lebih lengkap perkembangan kurs Rp/US\$ selama periode 1980-2007 dapat dilihat pada gambar berikut ini :

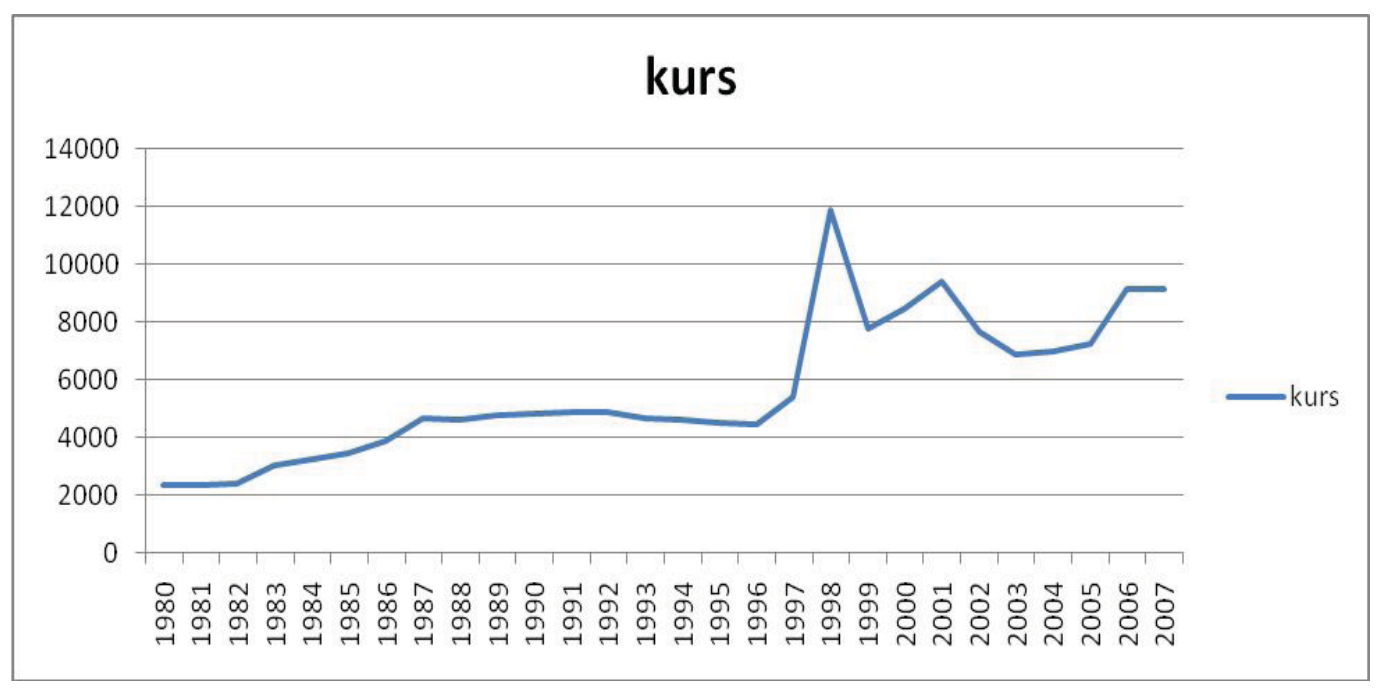

Gambar 2. Perkembangan Kurs Rp/US\$

Sumber : Asian Development Bank, 2009

Krisis ekonomi yang terjadi pada tahun 1997-2998 berdampak pada nilai kurs Rp terhadap US\$ yang semakin terdepresiasi. Apabila pada periode 1980-1996 nilai kurs Rp/US\$ berkisar pada rata-rata angka Rp. 3.000,-/US\$, pada tahun 1997-2008 meningkat menjadi sekitar Rp. 8.000,-/US\$ hingga Rp.12.000,-/US\$. Pasca krisis ekonomi dan moneter, perkembangan kurs Rp/US\$ meningkat dibandingkan dengan periode 1980-1996 menjadi rata-rata sebesar Rp. 7000,/US\$ hingga Rp. 8.000,-/US\$. Perkembangan nilai kurs Rp/US\$ yang mangalami kenaikan ini menunjukkan bahwa mata uang Rupiah mengamali depresiasi terhadap mata uang US\$. Hal ini berarti dibutuhkan lebih banyak Rupiah untuk membeli sejumlah mata uang US\$. Apabila kondisi ini terus dibiarkan terjadi dapat mengakibatkan ketidakpercayaan pasar terhadap kekuatan mata uang Rupiah. Namun demikian juga perlu dicermati bahwa pasca krisis ekonomi dan monter pada tahun 1997-1998 nilai kurs Rp/US\$ relatif stabil walalupun terjadi depresiasi mata uang pada periode sebelumnya. 


\section{Produk Domestik Bruto (PDB)}

PDB mencerminkan sejumlah output yang dihasilkan oleh perekonomian pada suatu periode waktu tertentu. Pencapaian PDB tidak hanya melibatkan sejumlah sumber daya lokal saja, akan tetapi juga melibatkan sumber daya ekonomi yang berasal dari luar negeri. Adanya aliran modal asing (foreign direct investment) dan bantuan luar negeri dalam hal finansial dapat mempermudah pembiayaan pembangunan domestik. Kapabilitas anggaran pembangunan menjadi meningkat dan akibatnya akan tercipta unit-unit kegiatan ekonomi yang dapat dihasilkannya. Dampak dari aktivitas ekonomi tersebut pada akhirnya dapat meningkatkan nilai PDB Indonesia dari waktuke waktu. Secara garis besar perkembangan PDB Indonesia selama periode 1980-2007 dapat dilihat pada gambar berikut ini:

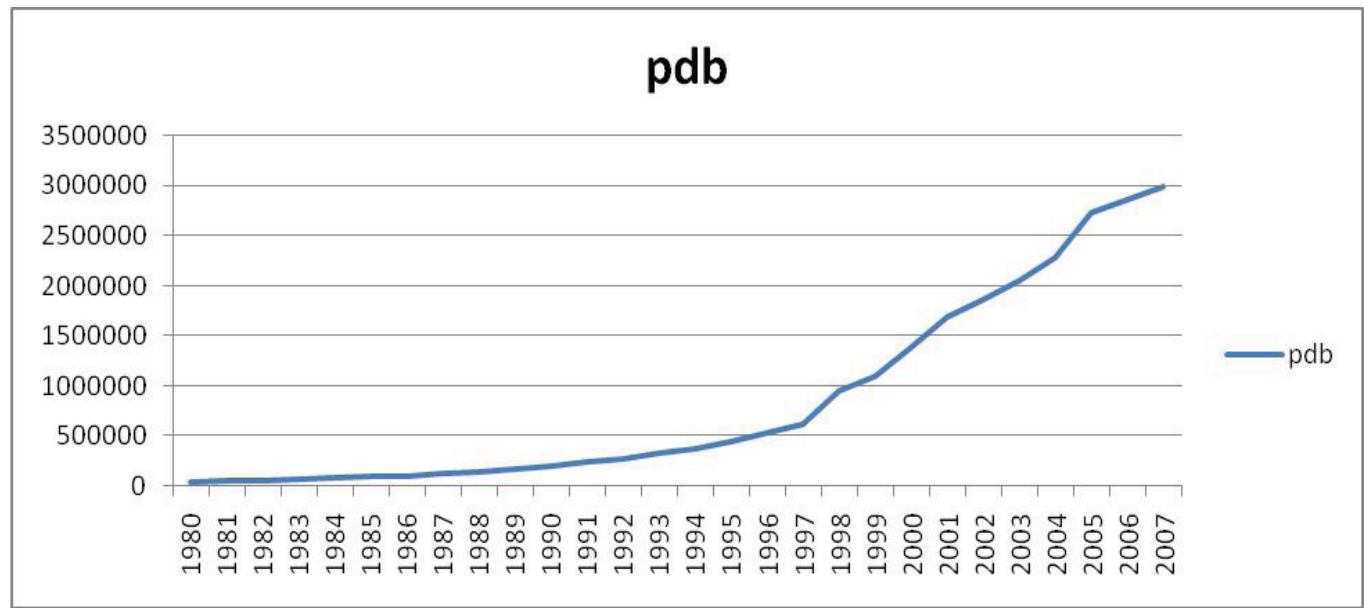

Gambar 3. Perkembangan PDB Indonesia

Sumber : Asian Development Bank, 2009

Secara rata-rata selama periode 1980-2007 terjadi trend kenaikan PDB Indonesia. Walaupun sedikit terjadi perlambatan ekonomi sebagai dampak krisis ekonomi dan moneter tahun 19961997, namun hal tersebut tidak mengurangi pertambahan output nasional secara agregat. Kenaikan output dalam perekonomian nasional tersebut menunjukkan bahwa iklim usaha di Indonesia masih cukup kondusif dalam pengembangan usaha yang ada. Hal ini tentunya ditopang oleh serangkaian kebijakan pemerintah dalam pembangunan yang lebih mengedepankan aspek pertumbuhan ekonomi dalam pencapaian keberhasilan pembangunan nasional dewasa ini.

\section{Tingkat Bunga}

Tingkat bunga perbankan mencerminkan besarnya biaya transaksi yang melibatkan institusi perbankan. Tingkat bunga tersebut dapat berupa tingkat bunga kredit dan tingkat bungan simpanan. Dalam hal ini besar kecilnya tingkat bunga kredit akan dipengaruhi oleh besarnya tingkat bunga 
simpanan. Semakin besar tingkat bunga simpan akan dapat mendorong kenaikan dalam tingkat kredit sebagai konsekuensi dari semakin tingginya beban yang harus ditanggung oleh fihak bank. Sebaliknya bagi nasabah pemiliki dana di bank, peneriman pendapatan dari bunga simpanan dananya di bank, merupakan bentuk insentif yang diberikan bank kepada nasabah. Hal ini juga sebagai bentuk penghargaan fihak bank keada nasabah yang telah mempercayakan sejumlah dananya untuk disimpan di lembaga perbankan; sebagai gambaran lihat gambar 4:

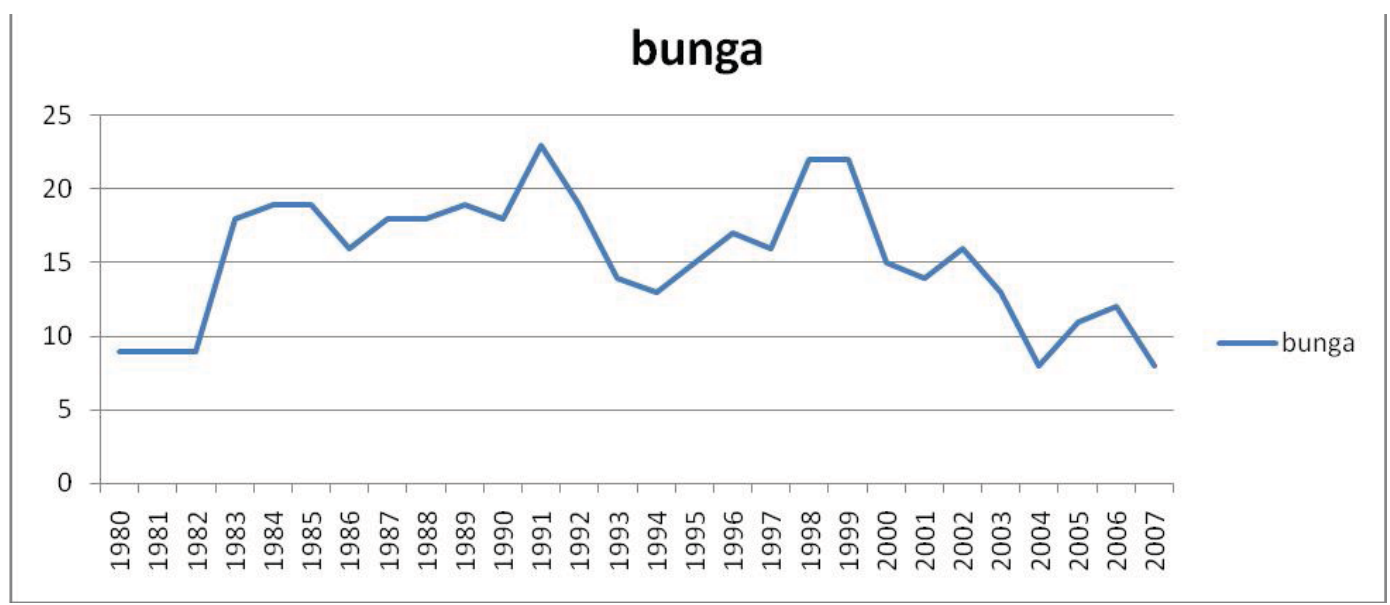

Gambar 4. Perkembangan Tingkat Bunga Simpanan Deposito 6 Bulan di Indonesia Sumber : Asian Development Bank, 2009

Selama periode 1980-2007 perkembangan tingkat bunga simpanan deposito 6 bulan di perbankan Indonesia mengalami fluktuasi. Krisis ekonomi dan monter yang terjadi selama periode 1997-1998 ikut mendorong kenaikan tingkat bunga demestik. Hal ini terjadi sebagai antisipasi dari otoritas moneter untuk menjaga agar dana pihak ketiga di perbankan tetap aman dan untuk menjaga agar nasabah tidak melakukan rush. Hal ini dilakukan dengan menaikkan besarnya tingkat bunga simpanan yang ada, sehingga masyarakat masih memiliki persepsi adanya insentif yang menarik bagi dana yang disimpannya dalam perbankan. Namun demikian juga patut dicermati bahwa naik turunnya tingkat bunga akan sangat sensitif dalam mempengaruhi kinerja perekonomian. Tingkat bunga yang terlalu tinggi juga dapat menghambat kegiatan investasi. Sebaliknya tingka bunga yang terlalu rendah, juga akan dapat mengurangi kemampuan perbankan dalam menjalankan fungsi intermediasi khsusunya dalam pembiayaan investasi dalam pembangunan negara. 


\section{Financial Deepening}

Sektor keuangan dan moneter merupakan salah satu penopang dalam kegiatan ekonomi di Indonesia. Keberadaan sektor ini selain dapat dilihat dari perkembangan dalam lemaga keuangan baik bank dan non bank, juga dapat dilihat dari perkembangan dalam jumlah uang beredar (money supply). Jumlah uang beredar menunjukkan sejumlah uang yang beredar di masyarakat dalam kaitannya dengan kegiatan ekonomi yang dijalankannya. Besar kecilnya dalam jumlah uang beredar tersebut akan mencerminkan seberapa dalam (shallow) dan seberapa dangkal (hallow) sektor keuangan suatu negara. Dalam hal ini ukuran financial deepening (FD) merepresentasikan perkembangan sektor keuangan suatu negara. Ukuran financial deepening tersebut dapat dilihat dari perkembangan rasio jumlah uang beredar terhadap PDB. Adapun sebagai perkembangan dari financial deepening di Indonesia dapat dilihat pada gambar berikut ini :

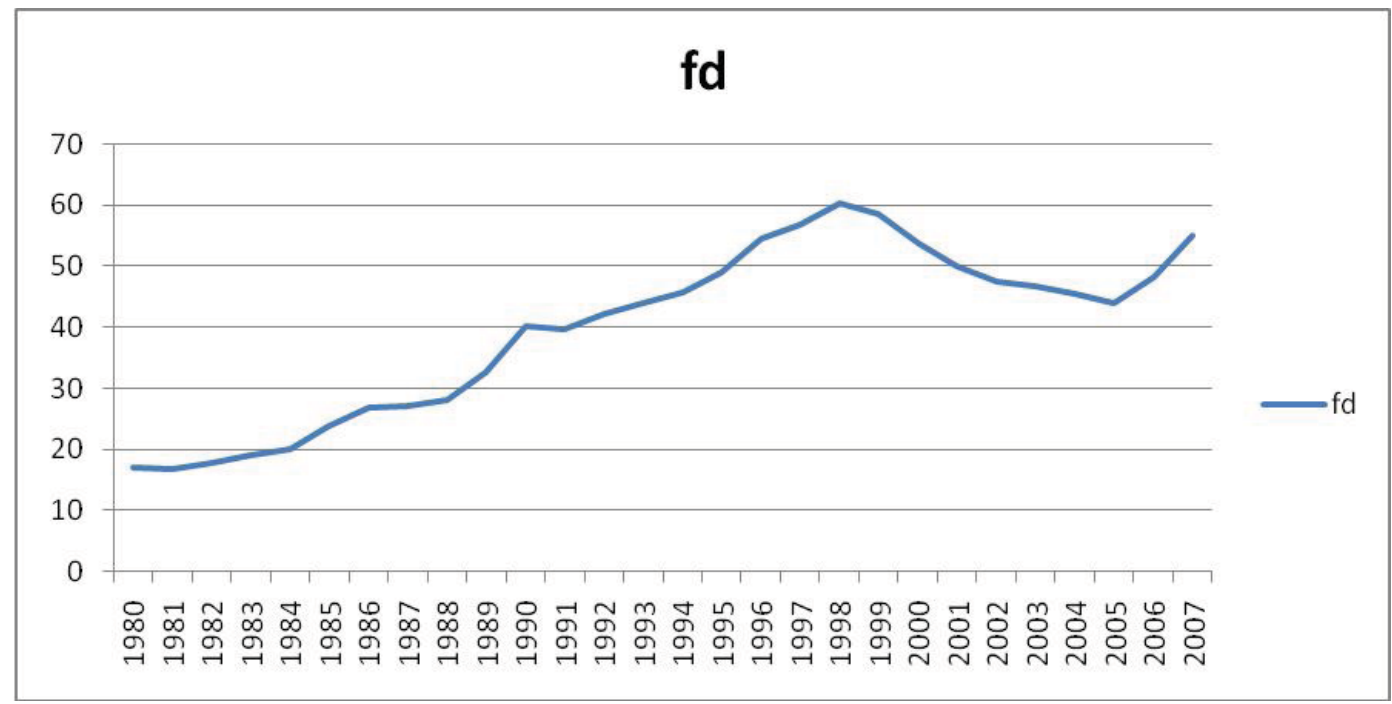

Gambar 5. Perkembangan Financial Deepening Indonesia

Sumber : Asian Development Bank, 2009, diolah

Perkembangan financial deepening di Indonesia selama periode 1980-2007 menunjukkan trend yang relatif meningkat. Tidak seperti pada kurs nilai tukar dan tingkat suku bunga, perkembangan financial deepening Indonesia lebih mencerminkan kerberhasilan dari otoritas moneter dalam meningkatkan likuiditas dan monetisasi masyarakat melalui sektor perbankan. Krisis ekonomi dan moneter yang terjadi pada tahun 1997-1998 justru meningkatkan financial deepening Indonesia. Hal ini dapat terjadi karena adanya berbagai insentif yang diberikan oleh otoritas moneter kepada masyarakat dalam menjalankan aktifitas ekonominya. 


\section{Hasil Analisis Data}

Berdasarkan oleh data dengan menggunakan program eviews, dapat dihasilkan output dari estimasi fungsi financial deepening Indonesia selama tahun 1980-2007. Secara lebih lengkap hasil oleh data dapat dilihat sebagai berikut ini :

Tabel 1. Hasil Pengolahan Data

Dependent Variable: LFD

Method: Least Squares

Date: 07/22/09 Time: 06:08

Sample: 19802007

Included observations: 28

\begin{tabular}{lllll}
\hline \hline Variable & Coefficient & Std. Error & t-Statistic & Prob. \\
\hline \hline C & -0.325650 & 1.111286 & -0.293039 & 0.7720 \\
LER & -0.025041 & 0.255109 & -0.098158 & 0.9226 \\
IR & 0.030306 & 0.010935 & 2.771558 & 0.0106 \\
LPDB & 0.285637 & 0.083984 & 3.401108 & 0.0024 \\
\hline \hline R-squared & 0.825112 & Mean dependent var & 3.607444 \\
Adjusted R-squared & 0.803251 & S.D. dependent var & 0.414952 \\
S.E. of regression & 0.184058 & Akaike info criterion & -0.415569 \\
Sum squared resid & 0.813056 & Schwarz criterion & -0.225254 \\
Log likelihood & 9.817964 & F-statistic & 37.74354 \\
Durbin-Watson stat & 0.588665 & Prob(F-statistic) & 0.000000 \\
\hline \hline
\end{tabular}

Berdasarkan pada hasil olah data di atas dapat dijelaskan bahwa diantara variabel-variabel yang mempengaruhi financial deepening Indonesia hanya tingkat bunga dan pendapatan yang memiliki pengaruh siginifikan. Sedangkan variabel lainnya, yakni kurs nilai tukar Rp/US\$ tidak memiliki pengaruh yang signifikan terhadap perkembangan financial deepening di Indonesia selama periode 1980-2007. Hal ini dapat dilihat dari nilai t statistik dan nilai $p$ value pada output di atas. Sedangkan nilai tukar Rp/US\$ tidak memiliki pengaruh terhadap financial deepening di Indonesia selama periode 1980-2007. Dalam hal ini variabel tingkat suku bunga memiliki koefisien sebesar 0,03. Hal ini berarti bahwa apabila variabel lain dianggap konstan, maka kenaikan pada tingkat suku bunga 1\% akan dapat meningkatkan financial deepening rata-rata sebesar $0,03 \%$. Sedangkan koefisien variabel pendapatan nasional sebesar 0,29. Hal ini berarti bahwa apabila variabel lain dianggap konstan, kenaikan 1\% pada pendapatan nasional akan dapat meningkatkan rata-rata sebesar $0,29 \%$ pada financial deepening Indonesia.

Namun demikian secara simultan variabel-variabel nilai kurs Rp/US\$ (LER), tingkat suku bunga (IR) dan pendapatan nasional (LPDB) memiliki pengaruh yang signifikan terhada variabel financial deepening Indonesia. Hal ini dapat dilihat dari besarnya angka pada nilai $\mathrm{F}$ hitung sebesar 37,74 yang jauh lebih besar dari angka tabel F kritisnya. Koefisien determinasi dari hasil estimasi di atas sebesa $0,83 \%$. Hal ini berarti bahwa variabel kurs, tingkat bunga dan pendapatan nasional mampu menjelaskan variasi perkembangan dalam financial deepening Indonesia selama periode 1980-2007 sebesar 83\%. Sedangkan sisanya sebesar 17\% dijelaskan oleh variabel lainnya 
yang tidak dimasukkan dalam model estimasi. Variabel lain tersebut dapat berupa variabel ekonomi, non ekonomi, kebijakan otoritas moneter, perilaku/persepsi masyarakat dan kondisi eksternal lainya.

\section{Uji Asumsi Klasik}

\section{A. Normalitas}

Uji normalitas dilakukan dengan menggunakan uji Jarque Bera test. Normalitas dari hasil estimasi di atas dapat dilihat secara praktis dari nilai $\mathrm{P}$ value yang dihasilkan dari perhitungan. Berdasarkan pada output di atas dapat dilihat bahwa nilai $\mathrm{P}$ value lebih besar dari tingkat keyakinan pada model estimasi (10\%). Secara lebih lengkap hasil uji jarque bera dapat dilihat pada gambar berikut ini :

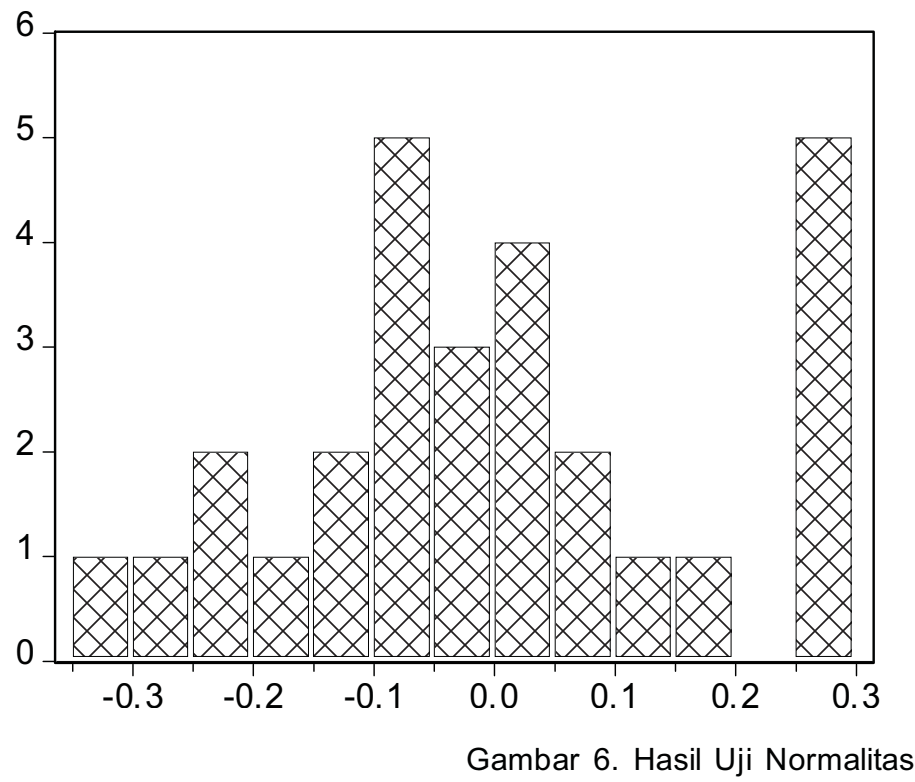

\begin{tabular}{|lr|}
\hline \multicolumn{2}{|l|}{ Series: Residuals } \\
Sample 1980 2007 \\
Observations 28 \\
\\
Mean & $7.05 \mathrm{E}-16$ \\
Median & -0.014488 \\
Maximum & 0.299877 \\
Minimum & -0.310328 \\
Std.Dev. & 0.173531 \\
Skewness & 0.154622 \\
Kurtosis & 2.274756 \\
& \\
Jarque-Bera & 0.725213 \\
Probability & 0.695860 \\
\hline
\end{tabular}

\section{B. Homoskedastis}

Uji Homoskedastis merupakan salah satu asumsi klasik yang harus dipenuhi oleh penaksir $O L S$. Uji heteroskedastis dalam asumsi OLS klasik digunakan untuk mengetahui apakah error term (residu) sama untuk semua observasi atau tidak. Hipotesis utama dalam uji ini adalah tidak adanya heteroskedastis terhadap error term (residu) hasil estimasi. Untuk mengetahui heteroskedastisitas dilakukan dengan menggunakan Uji White. Adapun hasil dari uji adanya heteroskedastis dalam model estimasi adalah sebagai berikut ini : 
Tabel 2. Hasil Uji Homoskedastis

White Heteroskedasticity Test:

\begin{tabular}{llll}
\hline \hline F-statistic & 3.749941 & Probability & 0.010789 \\
Obs*R-squared & 14.48265 & Probability & 0.024686 \\
\hline \hline
\end{tabular}

Test Equation:

Dependent Variable: RESID $²$

Method: Least Squares

Date: 07/22/09 Time: 06:12

Sample: 19802007

Included observations: 28

\begin{tabular}{lllll}
\hline \hline Variable & Coefficient & Std. Error & t-Statistic & Prob. \\
\hline \hline $\mathrm{C}$ & 2.339297 & 2.405544 & 0.972461 & 0.3419 \\
LER & -0.834022 & 0.651549 & -1.280061 & 0.2145 \\
$\mathrm{LER}^{\wedge} 2$ & 0.040944 & 0.036944 & 1.108269 & 0.2803 \\
$\mathrm{IR}$ & 0.026806 & 0.009588 & 2.795886 & 0.0108 \\
$\mathrm{IR} 2$ & -0.000781 & 0.000298 & -2.623784 & 0.0159 \\
$\mathrm{LPDB}$ & 0.207987 & 0.155454 & 1.337935 & 0.1952 \\
LPDB 2 & -0.006406 & 0.005927 & -1.080831 & 0.2920 \\
\hline \hline R-squared & 0.517237 & Mean dependent var & 0.029038 \\
Adjusted R-squared & 0.379305 & S.D. dependent var & 0.033387 \\
S.E. of regression & 0.026303 & Akaike info criterion & -4.225919 \\
Sum squared resid & 0.014529 & Schwarz criterion & -3.892868 \\
Log likelihood & 66.16286 & F-statistic & 3.749941 \\
Durbin-Watson stat & 1.464682 & Prob(F-statistic) & 0.010789 \\
\hline \hline
\end{tabular}

Berdasarkan pada output di atas, dapat diketahui bahwa model estimasi memperlihatkan adanya penyakit klasik, yakni lolos uji homoskedastis. Hal ini dapat diketahui dari nilai $p$ value yang lebih besar dari tingkat keyakainan tertentu (1\%) pada uji white heteroskedasticity.

\section{Uji Linieritas}

Uji ini digunakan untuk melihat spesifikasi model yang akan digunakan dalam estimasi sudah benar atau belum. Uji linearitas dilakukan karena adanya kesalahan spesifikasi model dapat berakibat ketidakefisienan dari penaksir. Hipotesis utama dalam uji ini adalah adanya linieritas dalam spesifikasi model Guna mengetahui linearitas model, maka digunakan general test of specification yaitu Ramsey RESET Test. Hipotesis utama dalam uji linearitas ini adalah model yang digunakan linear. Adapun hasil dari output uji linieritas dapat dilihat sebagai berikut ini : 
Tabel 3. Hasil Uji Linieritas

Ramsey RESET Test:

\begin{tabular}{llll}
\hline \hline F-statistic & 3.867463 & Probability & 0.061411 \\
Log likelihood ratio & 4.351810 & Probability & 0.036970 \\
\hline \hline
\end{tabular}

Test Equation:

Dependent Variable: LFD

Method: Least Squares

Date: 07/22/09 Time: 06:20

Sample: 19802007

Included observations: 28

\begin{tabular}{lllll}
\hline \hline Variable & Coefficient & Std. Error & t-Statistic & Prob. \\
\hline \hline C & -8.201103 & 4.140075 & -1.980907 & 0.0597 \\
LER & -0.035777 & 0.241174 & -0.148345 & 0.8834 \\
IR & 0.131894 & 0.052681 & 2.503652 & 0.0198 \\
LPDB & 1.318881 & 0.531362 & 2.482078 & 0.0208 \\
FITTED^2 & -0.525468 & 0.267198 & -1.966587 & 0.0614 \\
\hline \hline R-squared & 0.850286 & Mean dependent var & 3.607444 \\
Adjusted R-squared & 0.824249 & S.D. dependent var & 0.414952 \\
S.E. of regression & 0.173959 & Akaike info criterion & -0.499562 \\
Sum squared resid & 0.696020 & Schwarz criterion & -0.261668 \\
Log likelihood & 11.99387 & F-statistic & 32.65665 \\
Durbin-Watson stat & 0.500208 & Prob(F-statistic) & 0.000000 \\
\hline \hline
\end{tabular}

Berdasarkan pada output di atas dapat dijelaskan bahwa hasil uji lnieritas menunjukkan bahwa model estimasi lolos uji linieritas. Hal ini terjadi karena nilai $p$ value dari persamaan di atas lebih besar dari tingkat keyakinan tertentu (1\%) pada uji ramsey reset.

\section{Uji Autokorelasi}

Uji autokorelasi dalam asumsi OLS digunakan untuk mengetahui ada tidaknya hubungan antara residual untuk kurun waktu tertentu dengan residual kurun waktu sebelumnya atau adakah terjadi serial korelasi antar residunya. Hipotesis utama yang diajukan dalam uji ini adalah tidak adanya hubungan serial antara residual dengan observasi (nonautokorelasi). Autokorelasi dapat terjadi bila variabel gangguan pada periode tertentu berkorelasi dengan variabel gangguan pada periode yang lain. Bila hal ini terjadi, maka akan dihasilkan penaksir yang tidak efisien, walaupun estimasinya tidak bias. Uji dilakukan dengan menggunakan pendekatan uji Breusch dan Godfrey (B-G). Adapun hasil dari uji B-G dapat dilihat pada output berikut ini : 
Tabel 4. Hasil Uji Autokorelasi

Breusch-Godfrey Serial Correlation LM Test:

\begin{tabular}{lccc}
\hline \hline F-statistic & 12.35814 & Probability & 0.000253 \\
Obs*R-squared & 14.81402 & Probability & 0.000607 \\
\hline \hline
\end{tabular}

Test Equation:

Dependent Variable: RESID

Method: Least Squares

Date: 07/22/09 Time: 06:21

Presample missing value lagged residuals set to zero.

\begin{tabular}{lllll}
\hline \hline Variable & Coefficient & Std. Error & t-Statistic & Prob. \\
\hline \hline C & 0.040675 & 0.813291 & 0.050012 & 0.9606 \\
LER & 0.030676 & 0.192317 & 0.159505 & 0.8747 \\
IR & -0.007868 & 0.008765 & -0.897699 & 0.3791 \\
LPDB & -0.013961 & 0.064280 & -0.217192 & 0.8301 \\
RESID(-1) & 0.779005 & 0.222192 & 3.506001 & 0.0020 \\
RESID(-2) & -0.041376 & 0.244570 & -0.169181 & 0.8672 \\
\hline \hline R-squared & 0.529072 & Mean dependent var & $7.05 E-16$ \\
Adjusted R-squared & 0.422043 & S.D. dependent var & 0.173531 \\
S.E. of regression & 0.131925 & Akaike info criterion & -1.025762 \\
Sum squared resid & 0.382891 & Schwarz criterion & -0.740290 \\
Log likelihood & 20.36067 & F-statistic & 4.943256 \\
Durbin-Watson stat & 1.631914 & Prob (F-statistic) & 0.003494 \\
\hline \hline
\end{tabular}

Berdasarkan pada output di atas menunjukkan bahwa hasil estimasi menunjukkan adanya pelangaran uji asumsi klasik tentang non autokorelasi. Hal ini dapat dilihat dari besarnya nilai p value yang lebih kecil dari tingkat keyakinan tertentu $(1 \%, 5 \%$ dan $10 \%)$ pada uji Breusch dan Godfrey $(B-G$ test $)$ di atas.

\section{E. Uji Mulikolinier}

Multikolinieritas itu sendiri pertama kali diperkenalkan oleh Ragnar Frisch tahun 1934. Menurut Frisch, suatu model regresi dikatakan terkena multikolinieritas bila terjadi hubungan linear yang perfect atau exact di antara beberapa atau semua variabel bebas dari suatu model regresi. Akibatnya akan terdapat kesulitan untuk dapat melihat pengaruh variabel bebas terhadap variabel terikatnya. Hipotesis utama dalam uji ini adalah tidak adanya hubungan linear di antara variabel bebasnya. Guna mendeteksi adanya multikolinieritas dalam suatu persamaan regresi dapat dihitung dari nilai koefisen korelasi parsial (rij) yang diperhitungkannya. Apabila nilai koefisien dari korelasi parsial sangat kecil maka diduga tidak terjadi multikolinieritas. Adapun hasil dari uji multikolinieritas dapat dilihat pada output berikut ini:

Tabel 5. Hasil Uji Multikolinier

\begin{tabular}{|l|l|l|l|}
\hline \multicolumn{1}{|c|}{ LER } & \multicolumn{1}{c|}{ IR } & LPDB \\
\hline LER & 1.000000 & 0.108236 & 0.910762 \\
\hline IR & 0.108236 & 1.000000 & -0.171824 \\
\hline LPDB & 0.910762 & -0.171824 & 1.000000 \\
\hline
\end{tabular}


Berdasarkan pada hasil uji multikolinieritas dengan pendekatan koefisein korelasi di atas dapat disimpulkan bahwa hasil estimasi tidak lolos uji multikolinieritas. Hal ini terjadi karena nilai koefisien korelasi relatif besar, yakni antara variabel LER dan LPDB dengan koefisien sebesar 0,91 . Sedangkan koefisien variabel bebas lainnya relatif kecil.

\section{Pembahasan}

Dinamika perekonomian nasional selama tahun 1980-2007 ditandai oleh krisis keuangan yang terjadi baik pada tahun 1997 maupun yang terjadi pada tahun 2005. Krisis yang terjadi membawa dampak pada fundamental perekonomian khususnya pada sektor keuangan. Sektor keuangan merupakan salah satu sektor penting dalam menjaga likuiditas perekonomian. Adanya goncangan yang terjadi pada sektor keuangan tersebut akan mempengaruhi kinerja perekonomian baik secara makro maupun secara mikro. Hal ini terjadi karena sektor keuangan dapat berperan sebagai intermediary function dalam memberdayakan perekonomian melalui pembiayaan investasi dan penyediaan alat moneter bagi transaksi perekonomian masyarakat.

Mencermati benang merah yang terjadi dalam integrasi perekonomian global tersebut, maka dinamika yang terjadi di pasar keuangan sangat cepat dan volatilitasnya sangat tinggi. Pada indikator nilai tukar mata uang, depresiasi atau apresiasi nilai tukar mata uang di suatu negara akan cepat menjalar (efek domino) ke perekonomian negara lain. Pengangguran, inflasi, output (PDB), dan tingkat bunga dalam negeri akan bergerak melakukan penyesuaian sebagai respon dari efek domino yang terjadi.

Pergerakan nilai tukar mata uang merupakan konsekuensi dari adanya interaksi yang terjadi diantara pelaku ekonomi di berbagai negara dalam melakukan transaksi kegiatan ekonominya. Interakasi ini akan semakin meningkat seiring dengan meningkatnya kegiatan ekonomi di berbagai negara. Peningkatan arus barang, jasa dan modal antar negara pada akhirnya dapat mempengaruhi pergerakan nilai tukar mata uang antar negara. Ketidakstabilan dalam pergerakan nilai tukar mata uang dapat berakibat pada ketidakstabilan makroekonomi suatu negara. Oleh karena itu guna menjaga kestabilan makroekonomi suatu negara, maka kebijakan moneter yang mengarah pada kestabilan nilai tukar mata uang domestik terhadap mata uang asing menjadi sangat diperlukan.

Namun demikian berdasarkan hasil analisis di atas dapat dijelaskan bahwa nilai tukar $\mathrm{Rp} /$ US\$ tidak mempengaruhi financial deepening di Indonesia. Sebagaimana dijelaskan di atas pergerakan kurs nilai tukar Rp/US\$ di Indonesia bersifat flexible exchange rate. Pergerakan nilai kurs akan sangat ditentukan oleh kekuatan demand dan supply dari pelaku keuangan di pasar uang. Tidak adanya pengaruh kurs nilai tukar Rp/US\$ dengan financial deepening mencerminkan adanya pemisahan antara pasar uang dengan sektor perbankan. Hal ini terjadi karena persepsi perilaku masyarakat di pasar uang (kurs mata uang) dengan persepsi masyarakat di sektor perbankan berbeda. Perilaku masyarakat di sektor perbankan lebih didasarkan pada estimasi jangka panjang dalam investasi dananya dengan lebih mengedepankan aspek keamanan dananya. Sedangkan persepsi masyarakat di pasar uang lebih didasarkan pada pertimbangan profit yang besar dengan adanya resiko fluktuasi nilai kurs mata uang yang ada di pasar. 
Pada indikator tingkat bunga, adanya tekanan pada harga saham dan nilai tukar mata uang khususnya Rp/US\$, akan membawa daampak pada perilaku otoritas moneter dalam menjaga stabilitas perekonomian. Otoritas moneter akan melakukan kebijakan yang bersifat trade off. Dengan kata lain untuk menjaga agar likuiditas keuangan masyarakat tetap terjaga stabil, maka dalam hal ini Bank Indonesia akan melakukan perubahan kebijakan dengan menaikkan tingkat bunga perbankan dalam negeri. Upaya ini dimaksudkan untuk memberikan insentif bagi masyarakat agar tetap menaruh dananya pada sektor perbankan nasional. Dengan kondisi ini maka pendalaman sektor keuangan (financial deepening) dalam perekonomian nasional akan tetap terjaga.

Berdasarkan pada hasil analisis di atas, dapat ditemukan suatu output bahwa tingkat suku bunga mempengaruhi secara positif signifikan terhadap financial deepening di Indonesia. Hal ini terjadi karena secara teoritis kenaikan tingkat bunga tersebut akan dapat meningkatkan insentif yang diterima masyarakat yang menyimpan dananya di Bank. Menurut Mc Kinnon dan Shaw (1973) liberalisasi sektor keuangan yang ditandai dengan kenaikan tingkat bunga perbankan akan memberikan dampak pada semakin banyaknya dana masyarakat yang disimpan di sektor perbankan. Hal ini berarti bahwa dana fihak ketiga yang ada di bank akan semakin meningkat dan hal tersebut pada akhirnya dapat meningkatkan rasio keuangan (money supply) terhadap PDB. Indikator financial deepening yang ditandai dengan semakin besarnya rasio money supply (M2) terhadap PDB akan semakin meningkat sebagai konsekuensi dari kenaikan insentir yang diterima masyarakat dalam bentuk kenaikan tingkat bungan perbankan.

Indikator PDB hingga kini masih diyakini sebagai salah satu indikator dalam menilai kinerja perekonomian suatu Negara. Nilai yang tertera di dalamnya mencerminkan sejunlah output perekonomian yang dihasilkan oleh pelaku ekonomi dengan pemanfaatan segenap sumber daya ekonomi yang ada. Berdasarkan hasil analisis di atas dapat diperlihatkan bahwa PDB memiliki pengaruh yang signifikan terhadap financial deepening Indonesia. Hal ini terjadi karena dengan semakin besarnya PDB yang ada membawa konsekuensi pada semakin besar pula money supply yang dibutuhkan masyarakat dalam perekonomian. Hal ini pada akhirnya akan dapat meningkatkan rasion keuangan dengan PDB.

Pada sisi lain juga dapat dijelaskan bahwa kenaikan dalam PDB akan membawa implikasi pada semakin besarnya tingkat likuiditas moneter dalam perekonomian. Semakin besarnya output yang dihasilkan, akan meningkatkan volume transaksi ekonomi masayarakat. Kenaikan volume transaksi ini akan dapat meningkatkan transaksi moneter masyarakat dalam perekonomian. Dalam hal ini menurut pemikiran moneter Irving Fisher, money supply dapat dicapai dengan mengetahui tingkat kecepatan peredaran uang (velocity of money). Kondisi money supply ini akan dapat diimbangi dengan money demand yang dibangun dengan indicator tingkat harga dan besarnya transaksi ekonomi yang terjadi. Semakin besarnya money supply yang ada pada dasrnya juga mengindikasikan adanya kenaikan dalam transaksi ekonomi dalam perekonomian manakala diasumsikan pasar dalam keadaan seimbang (equilibrium). 


\section{Kesimpulan}

Berdasarkan pada hasil analisis yang diperoleh pada penelitian ini didapatkan kesimpulan penelitian sebagai berikut ini :

a. Variabel tingkat bunga dan pendapatan nasional memiliki pengaruh signifikan terhadap financial deepening Indonesia selama tahun 1980-2007. Sedangkan variabel kurs nilai tukar Rp/US\$ tidak memiliki pengaruh terhadap financial deepening Indonesia.

b. Diantara variabel-variabel yang ada, variabel pendapatan nasional memiliki penaruh terbesar terhadap perkembangan financial deepening di Indonesia selama tahun 1980-2007.

\section{Saran}

Adapun saran yang dapat disampaikan pada penelitian ini adalah :

a. Untuk menjaga stabilitas keuangan dan moneter di Indonesia dibutuhkan sinergi kebijakan otoritas moneter yang melibatkan pelaku di pasar uang dan di perbankan. Hal ini karena ketidaksatabilan yang terjadi di sektor moneter dan perbankan akan dapat mempengaruhi perkembangan pada financial deepening.

b. Fluktuasi yang terjadi pada tingkat bunga dan nilai tukar merupakan fenomena pasar yang mesti direspon secara positif oleh otoritas moneter. Fluktuasi yang terlalu tajam akan dapat berdampak pada respon pasar yang negatif manakala otoritas moneter tidak mampu mengendalikan pasar. Oleh karena itu untuk menjaga agar financial deepening tetap memiliki trend positif dalam perkembangannya, perlu dilakukan kebijakan ealy warning system pada perkembangan di sektor keuangan, perbankan dan moneter.

\section{DAFTAR PUSTAKA}

Agrawal, Pradeep, 2001,'Interest Rate, Exchange Rates and Financial Deepening in Selected Asian Economies", ASEAN Economic Bulletin, Vol.18,No.1 : 83-93

Brandl, Michael W,2002.'The Role of Financial Institution in Long Run Economic Growth",www.buc.utexas.edu/faculty/Michael.brandl,:12-02-02

Cull, Robert, 2001,'Financial Sector Reform : What Works and What Doesn't',Economic Development and Cultural Change, Vol.49,no.2, Januari : 269-290

Dornbusch, Rudigner dan Alejandro Reynoso, 1989,"Financial factors ini Economic Development",American Economic Review,Vol.79.no.2 : 204-209

Kitchen, Richard L, 1988. Finance for The Developing Countries, John Wiley \& Sons, New York Kuncoro, Mudrajad. 1996. Manajemen Keuangan Internasional, Edisi Pertama, BPFE-Yogyakrata

Levine, King dan Ross Levine, 1993,'Finance and Growth : Schumpeter Might be Right", Quartely Journal of Economics, Vol.CVIII, Agustus : 716-737 
Lynch, David, 1996,'Measuring Financial Sector Development : A Study of Selected Asia Pacific Countries", Developing Economies, No.XXXIV-1,Maret : 3-33

Nasution, Anwar, 1991,'Perkembangan Perekonomian Indonesia 1987-199, Dampak jangka Pendek dan Implikasi Jangka Panjang”, Prisma, No.9, Tahun XX, September : 32-60

Okuda, Hidenobu. 1990.'Financial Factors in Economic Development : A Study of The Financial Liberalization Policy in The Philippines", Developing Economies, No. XXVIII,September, New York

Wardhono, Adhitya, 1998,"Analisa Faktor-faktor Penentu Tingkat Bunga Nominal di Indonesia dan Philipina : Pendekatan Model Backward dan Forward Looking",Tesis S2 Pasca Sarjana UGM, tidak dipublikasikan, Yogyakarta 